\title{
Corruption, the Challenge for Kosovo Institutions
}

\author{
Mr.Sc. Reshat Maliqi, PhD Cand. \\ Kosovo Police Colonel \\ reshatmaliqi60@gmail.com
}

\begin{abstract}
The subject as per work, corruption, the challenge for Kosovo institutions, is broadly and actual theme that covers the theoretical and practical treatment. The corruption, which has been described as using the public power for certain purposes, is a very complex subject. Stands for the characteristics of many societies and states and for the last couple of years it has been understood as in great form present phenomenon within the countries in transition, within those which are undeveloped as well as with developed ones, and stands for an obstacle for democracy implementation. From a systematically point of view, corruption has caused, and it continues to do so, many concerns in all countries on Earth, and especially in Kosovo. In accordance to Transparency International report, corruption is one of the biggest challenges of contemporary world. The aim of the importance of studying of this problem through this subject is identifying the scope, structure and dynamics of this phenomenon; to analyse overall impact of general factors. In accordance to identification of corruption problems, local and international reports with of high level of this kind of criminal act, among other areas as well as per security issues, corruption has been seen as serious wound for our society. The justification of this work is logical consequence of corruption phenomenon in the Republic of Kosovo. The reason, consequences and the fight against the corruption is always the subject of numerous researches and conversation between researches, politicians and other actors dealing with this problem, not leaving aside the segment of civil society. These problems stand for the subject of study of this work from my point of view with the purpose of sharing the overall concern due to this phenomenon. During this study many different methodologies will be used, as well as the methodology of analyses of cases of corruption, method of comparative analyses, comparative methodology and statistical method of creation and fight against the corruption in Kosovo from $2012-2104$. For fight and suppression of corruption, the society and institutions in Kosovo, among the prevention measures, would have to implement so far reached measures in criminalistics in accordance to contemporary trends in secure management. The final aim of this work is practical use of its results and statistics in society's efforts to prevent, to limit or to eliminate the corruption phenomenon in Kosovo.
\end{abstract}

Keywords: corruption, prevention and fight against corruption, working methods, challenges, reasons, prevention, Kosovo, etc.

\section{Introduction}

Kosovo is well known as one of the poorest country of European countries. The level of unemployment is considered to be $42 \%$, which stands for the highest in Europe. Therefore, with that high percentage of unemployment and poverty the corruption in public sector blossoms. Today, in the world, all states are, or strive to be, democratic states. This particularity or form of self-government has its negative side, so except new benefits and new possibilities for society, brings different problems in society. One of the problems that democracy brings is corruption that is usually, as a phenomenon, distinct in all states. Corruption as a phenomenon enables the leaders to get rich - the rich that are corrupted, but immediate harms the state and indirectly the middle and lower level of society. Depends on the level of democracy and economic development the presence of corruption varies.

Taking into consideration the bitter experiences in other states the corruption in Kosovo presents a challenge that, apparently, would not be easy to deal with. Through this work I did my best to elaborate what is actually corruption and what consequence can get to a state in development or to an undeveloped state. The fight against the corruption is not easy one and we all have to give our contribution in order to win the fight against it. Therefore, taking as bases the 
experiences other countries had successfully fought the corruption; as well we would have to fight on the same manner if we want to build a successful country. We would have to go through this on different ways in order to as much as possible decrease problems and unsatisfactory that this decease causes, for the interest of people as well as for the building a strong, existing country".

\section{Spreading of corruption in Kosovo}

The timeframe and the process of democracy development can be an indicator of spreading and development of different forms of corruption. The processes of in ex-communist countries, as well as the move from authoritative to democratic rule, it is notable that the possibilities for appearance and spreading of corruption were created to a level of concern. In process of transition Kosovo as well goes through big challenges. Since the proclamation of independence Kosovo went through numerous of big and important processes of state building as well as the establishment of the mechanism for functionality of a juridical state, democratic and credible towards its citizens (Krasnqi A., 2013:51).

From local and international institutions and civil society institutions many researches have been made pertaining the spreading of corruption in Kosovo, and in same one part of citizens throughout Kosovo has been covered. An research conducted by UNDP (United Nations Development Program) on perception and citizen's assessment on this phenomenon with subject "Study on Kosovo citizens' perception according to Kosovo Strategy for fight against Corruption". Following results have been obtained: perception for corruption of Kosovo Government and the Office of the President of Kosovo $42 \%$ of interviewed people think that those institutions are "corrupted" and $13 \%$ share opinion that they are "very corrupted", (Krasniqi A., 2013:52).

In a questionnaire conducted by Kosovo Democracy Institute (KDI), which was at the same time the global barometer of corruption for 2010 as per Transparency International, 73\% of interviewed people in Kosovo share opinion that from 2007 the level of corruption has been increased and only $8 \%$ share opinion that corruption is decreasing; $61 \%$ said that measures against corruption didn't show any result, and only $8 \%$ are of opinion that the corruption has been decreased, $16 \%$ have given the bribe for performance of any kind of service. In accordance Transparency International's index of corruption perception for 2011 Kosovo marks the 2.9 level (level 1.12 stands for lowest corruption level) and it indicates the lowest in Balkans. In accordance to indicators presented by World Bank for Self-government, from 2003 the control of corruption has shown small improvements, but still this control continues to be weak. This year the increase of this control was 30\% (100\% shows full control over the corruption), with unclear variations from 2005 (Krasnqi A., 2013:53).

Regarding the confiscation and seizure of property, EU Rule of Law Mission in Kosovo (EULEX) has reported as follows: their mission has so far imposed a sentence for 15 cases of corruption where few cases were high profile cases, but any property acquired illegally in any of these cases has not been seized. This happened because of the "limited and weak capacities for seizure of properties acquired illegally due to the legal or institutional aspect" as reported by in May 2011 by Kosovo Institute for Policy Research and Development. And based on the estimations obtained from these institutions it is obvious that one of the primary problems of expansion and spreading of corruption are lack of clarity what kind of activity - illegal activities of Special agencies for anticorruption and determination of their duties and completely preserving their impartiality and independence. In order to eradicate the institutional corruption it is necessary to enhance the role of monitoring of the functional commission of the Kosovo Assembly on the Ministry of Justice and Ministry of Interior.

\section{Consequences and statistics of corruption in Kosovo}

Consequences of corruption in society are major, they can be even coated on top of each other, aggravating more and more their effect on the society and system in function. Therefore, we had so many warnings and evaluations by international institutions about danger and consequences this negative phenomenon could bring along, phenomenon that is too harmful. Starting from this, legislations have been drafted, mechanisms established, either international or local, with aim of preventing and combating this phenomenon, harmful and socially destructive. Consequences of corruption affect political, social, economic and psychological power.

Political consequences of corruption are really major. It can directly damage the purpose (goal) of democratization of the society, it is also a serious threat to entire political class. The corruption especially affects countries which are on their way of transition and those who face nonexistent political stability, (Krasniqi. A., 2013, :60). 
Economic consequences of corruption in such cases could be major. High level of corruption can affect a withdrawal of foreign investments, which every country has a great need for. Experience shows that people from the political milieu avoid investing in countries where the level of corruption and economical crime is high, because right at the beginning they would have to confront corrupted officers (officials), who for their personal gain are able to make it difficult for accommodating the foreign businesses, causing intentional delay of administrative procedures which very often look so complicated, and all for the sake of fulfilling their corrupted goals, (Halili. R., 2011:201).

Corruption cost Kosovo 100 million of euros every year, it was estimated by representatives of the civilian society and economic associations in the country. More than $20 \%$ of all the amounts of contracts on tenders concluded within one year, based on a research, are abused by officials in Kosovo institutions. Movement "FOL" which deals with evaluating of anticorruption combat, stated to Radio Free Europe that based on the research, one of the most corrupted sectors in Kosovo is procurement area and privatization process. Level of abuse in the procurement sector is $20 \%$, repeated Kalaja "If I'm talking numbers, every year through the procurement, Kosovo spends between 450 and 600 millions of Euro, which means that around $40 \%$ of Kosovo budget goes through the procurement process. 2 If we add another $20 \%$ that is being abused, then we come to a conclusion that over 100 million of Euro in one year is at risk of abuse from political officials through procurement process".

Second analysis of "FOL" movement refers to court decisions. Here also, some decisions made by courts in Kosovo show that Kosovo loses millions of euros because of the corruption. "We have a case of scandal with passports where the court confirmed that the budget of Kosovo was harmed for more than 1.5 million of Euro, and here we're talking about the court decision. These are the numbers that potentially harm Kosovo budged through corrupted affairs". Corruption in Kosovo, in different international reports was highlighted as one of the biggest challenges the authorities should encounter with. In 2014 Kosovo has shown a slight recovery but not the effective one in the corruption index that was published by Transparency International, comparing to Albania which is on $110^{\text {th }}$ place on the well-known "red zone". Representatives of the economic associations in Kosovo stated on the other side that tax evasion which is very high in Kosovo is tightly related to corruption which is already present in Kosovo institutions. President of the Business Alliance in Kosovo, in his statement for Radio Free Europe estimated that such informality in Kosovo is up to $40 \%$ and that the same values 1.5 billion euros.

This negative phenomenon unfortunately grows from year to year". According to an analysis made the by European Bank for Reconstruction and Development, (EBRD) corruption is of the main problems of management in Kosovo. Since the Action Plan for efficiency improvement in prosecutions, in combating the corruption entered into force in November 2013 and all the way to December 2014, prosecution had 1604 suspicious cases with 2709 individuals involved. Out of this number, the prosecution managed to resolve 566 cases with 1301 individuals involved, (Gnjonca.L., 2004:297).

\section{Institutional and legal mechanisms in preventing and combating corruption}

It has been emphasized that corruption is not a single internal question of a certain countries that have to deal with corruption problem but it's the part of international interest, (Gnjolca.L., 2004:297). During the last three years Kosovo has undertaken some important steps towards suppression of the corruption by implementing necessary elements within legal frame work: The law on declaration of assets, prevention of conflict of interests in performing public functions, informers, public procurement and financing of political parties. Existing legal frame work has very strong and sufficient provisions in order to provide us with tangible results in this area. Kosovo has established an Independent Anti-Corruption Agency in 2006. The agency is the main institution for supervising the law on preventing the conflict of interests and the law on declaration of assets of public officials, as well as the Anti-Corruption Strategy and the Action Plan. It also deals with the review of individual complaints on possible corruption cases and it is obliged to inform other similar authorities like: police and prosecution, if it finds reasons for further investigation.

According to evaluations done by Director of Anti-Corruption Agency Hasan Preteni, in his interview for "KPress"- it remains that the most corrupted institutions in Kosovo government, justice, municipalities and public companies. The highest level of corruption is present at the Ministry for Infrastructure, Ministry of Health, Ministry of Education and EKK, because those departments have the highest tenders. He is of the opinion that prosecutors are lacking the braveness but also power and professional braveness of judges to engage in combat against those corrupted cases. Mr Preteni continues with the same 
rhetoric, says that there is a lot of talk about the corruption, little is being investigated and none is being prosecuted. According to him, authorities are not accountable to justice and there is no transparency.

\section{(http://www.kosovopress.com/sq/nacionale/korrupsion-ka-spo-giykohet-fare-sepse-po-mungon-guximi-49009/)}

In February 2012, the president of Kosovo established the National Anti-Corruption Council. The council strives to improve coordination and to raise the awareness within the all entities and institutions that are involved in combat against the corruption. Source: (Decree no.:DKKK-001-2012, on establishment of the Anti-Corruption National Council (published in Official Gazette on 16.02.2012).

From the point of view of the administrative capacities, during the last three years, prosecution and police have been reorganized in order to improve the combat against the corruption. Within its structure, Kosovo Police has Directorate for Investigation of Economic Crimes and Corruption, which deals with preventing and solving of all economic crime cases (acts) that were aimed initially against the property rights, against the provision of payment services and anti-business, and later on against official duties, particularly in the economic area, but even in the area outside of economy (Veseli, L. 2006:20). The priorities in the work of the unit are: economic crime, financial crime, corruption, financial investigation, money laundering, cyber-crime, intellectual property. This police unit is monitoring and analyzing security situation related to the economic crime and corruption, and recommends drafting of new legal norms related to improvement (expansion) of its work, (Maslesha, R, 2008:266).

In 2010, a Special Prosecutor's Office has established a task force on anti-corruption, comprised of prosecutors (from Kosovo and EULEX) and police officials for the investigation. Source: (Announcement of Feasibility Study Commission for Agreement for Stabilization and Association Agreement between the European Union and Kosovo, Brussels, 10.10.2012, pg. 10.)The purpose of this Task Force is investigation of economic and financial crime. Police also established one Directorate against crime and corruption. Inspection Departments have been established in many authorities and institutions, for the purpose of addressing and monitoring the situation with regard to corruption and /or criminal behavior within the organization. Generally, Kosovo has sufficient elements which are set out in Legal framework, as well as relevant institutions. Within a short period, Kosovo has a need to demonstrate a clear engagement, in order to provide results in combating corruption, and also including in this way the beginning of the investigation, in cooperation with EULEX.

\section{Legal and strategic infrastructure for the treatment of corruption in Kosovo}

Policies and initiatives against corruption were in the focus of legal and institutional efforts, which have been carried out in recent years in Kosovo. In this string, one improvement was noticed by the stakeholders while treating challenges of the corruption, especially at the beginning of addressing the corruption cases, as well as improvement of the framework of current legislative structures for treating the corruption.

- The legal framework treating the corruption in Kosovo is:

- Law on Declaration, Origin and Control of the High Official's Property in Public Institutions No. 04/L-050

- Law on Prevention of Conflict of Interest in Discharge of Public Functions, No.04/L-051

- Law on Anti-corruption Agency, No.03/L-159

- Criminal Code of Kosovo

- Anti-corruption Strategy and Action Plan 2013 - 2017.

\section{Media and civil society in prevention of corruption}

If the role of government was more active and honest in terms of prevention of corruption, we would not have what to write about the role of media and civil society, about this epidemic. The role of public institutions, especially in the transition 
countries, is very mild, not to say that the beginning and the cultivation of corruption begins in these very institutions, (Salihu, I, 2012:106)

It is without a question that the state, through its own mechanisms, has the possibility to prevent spreading of corruption. In Kosovo, the role of media in reporting or showing cases and corruptive practice is increasing more by each day.

This is happening as a result of increasing independent media in the country, increasing level of professional development of journalists and the establishment of a legislative basis which supports press in data collection (information), especially in public institutions. The role of independent media, viewed from the point as an element to prevent crime in general, and especially corruption, is commendable, as irreplaceable. Media kicks on cases of corruption phenomena that are seen, will create a climate of belief and positive optimism in public, it would compel state entities to respond positively to embedding or improving the state of legality in the mentioned administration, it would give real effect of relevance of so-called civil society, (Ragipi, A, 2003:95).

The role of civil society in prevention of corruption is without a doubt very influential. The civil society includes those societies, structures that are separated from legislative, administrative and legal self-government authority, but have mutual interaction in many ways and many areas. In most cases, when strivings to combat corruption have failed, that is happening because this, so important element - civil society, was left out.

Source: (http://www.againstcorruption.eu/uploads/rapoarte_finale_PDF/Kosovo.pdf).

Engagement and mobilizing of civil society is a crucial element for success of every anti-corruption and anti- criminal strategy, (Ragipi,A,2003:105). Regardless of all of these entities, which are appearing and mentioning as preventers, again, situation in transitioning places remains merely an attempt, without serious and concrete impacts. This is happening because, the highest representative authority in society, and in this case that is state, has its flaws and its problems, which created for itself. Subsequently, an attempt to change some things from down to upwards becomes more difficult and complex, because the beam of authorities, breaking furiously and mercilessly the media membrane and the membrane of society, damages to a large extent and prevents those who want to do something good and reviving for their own place, (Veseli, L, 2012:196).

\section{Conclusion}

I can conclude that it is better to prevent disease than to carry out professional treatment of the disease. Moreover, if the state institutions, non-governmental organizations and ordinary civil society mean to persistently and with great determination carry out the prevention of corruption, then the treatment of corruption in Kosovo will be easier, having in mind that despite of great efforts, the first phase of prevention was unsuccessful. This happened because a lot of stakeholders and participants were identified in the first phase of presenting and development of corruption. The investigators that were dealing with study of the criminological, criminal and legal profession, the question of combating corruption was described from repressive and preventive angle, because, corruption as a special form of general crime, cannot be separated at all, except due to this kind of measures, which actually present elimination of this devastating phenomena, especially through institutional knowledge and criminal-state punishments.

Practical elements contributing to the reduction of corruption, in some hand a hope is created that the concerned phenomenon will not happen again, because it is historically known that those who have committed criminal acts, sooner or later were discovered, and then prosecuted. I've come to the conclusion that some of these elements that have preventive characteristics are: transparency - which is actually preventive element in order for phenomena to reduce rhythm or disappear in one institution. A part of these are; Publication of precise data for budget of the state, as well as publications related to the budget. Drafting practical conditions and full respect of the rights to public information. Public debate in cases where it is discussed about wealth or declaring it. Based on previous aspirations to combat corruption in Kosovo, I can say that the desired effect has not been achieved, so it is necessary to adopt a special law on anti-corruption, and to raise awareness of the citizens, which should be aimed at defining the conduct which is the subject of the termination of corruption and special areas that are too sensitive to corruption. The enactment of specific measures to combat, detect and investigate corruption. Ratification of international conventions in the area of criminal law. The enactment of the human and professional capacities of the Prosecutor's Office including the necessary level of security and adequate material 
compensation. Implementation of the current anticorruption legislation and its harmonization with the new procedures in the process of cooperation, ratification and signing of the international instruments of the criminal issues. Restructuring of the judiciary and revitalizing it with the new professional staff with no background. Enhancing the role of the Anti-corruption Agency and preserving its impartiality. We will have success in fighting corruption only if we are ready to make the proper decisions on concrete cases and how to bring to light all weaknesses of the state institutions.

\section{Literature}

$\underline{\text { Books literature }}$

Gjonca, L., The Corruption, Tirana 2004,

Halili, R., Criminology, Pristina, 2011,

Krasniqi, A., Corruption, Forms of Appearance and Suppression, Pristina, 2013,

Latifi, V., Politics of the Fight against Crime, Pristina, 2012,

Latifi, V., Criminalistics Tactics, Pristina, 2006,

Ragipi, A., Corruption and Fiscal Evasion, Tirana 2003,

Maslesa, R., Police and Society, Pristina, 2008,

Salihu, I., Economic Crime, Challenges of National Security of Albania, Kosovo and Macedonia of Economic Crime, Skopje, 2012,

Sadiku, L., Society against Corruption.

Articles from magazines and dailies

Announcement of Commission for Feasibility Study for Stabilization and Association Agreement between European Union and Kosovo, Brussels, 10.10.2012,

Decree no.: DKKK-001-2012, for Establishment of National Council Against Corruption (published in Official Gazette on 16.02.2012).

Internet source

http://www.againstcorruption.eu/uploads/rapoarte finale PDF/Kosovo.pdf

http://www.kosovapress.com/sq/nacionale/korrupsion-ka-spo-giykohet-fare-sepse-po-mungon-guximi-49009/ 